\title{
Failure to form a leamed taste aversion in rats with amygdaioid lesions
}

\section{ERNEST D. KEMBLE and JENNIFER A. NAGEL* Univeristy of Minnesota, .Morris, Minn. 56267}

Rats sustaining bilateral amygdaloid lesions failed to develop aversion to $0.1 \%$ saccharin solution after it had been paired with a $0.12 \mathrm{M} \mathrm{LiCl}$ injection. These data confirm an important role for the amygdaloid complex in the formation of learned taste aversion and further substantiate the role of this structure in a wide variety of aversively motivated behaviors.

Recently, Rozin \& Kalat (1971) have argued that data from both diet selection and taste aversion learning experiments make necessary the postulation of new learning principles which govern the feeding system. Since the amygdaloid complex is widely considered to be involved in the control of feeding (e.g., Goddard, 1964) as well as a variety of aversively motivated behaviors (e.g., Horvarth, 1963; Pellegrino, 1968; Ursin, 1965), it might be expected that amygdaloid damage would interfere with the formation of a learned taste aversion. Some data (McGowan, Hankins, \& Garcia, 1972; Rolls \& Rolls, 1973) have recently appeared which seem to support this expectation. McGowan et al (1972) found that amygdaloid damage interfered with a $\mathrm{LiCl}$-induced aversion to saccharin solution. However, these authors fail to report pretest levels of saccharin consumption. In view of a later report (Rolls \& Rolls, 1973). which reports increased comsumption of $25 \%$ sucrose solution following amygdaloid damage, the possibility that increased reactivity to saccharin solution in amygdaloid Ss offsets the aversive effects of $\mathrm{LiCl}$ cannot be ruled out. In a second report, appearing after completion of this experiment, Rolls \& Rolls (1973) observed that amygdaloid Ss generally failed to form an aversion to $\mathrm{NaCl}$ after $\mathrm{LiCl}$ consumption. Since the amount of $\mathrm{LiCl}$ consumed by both amygdaloid and control Ss varied widely, and since some amygdaloid Ss did form an aversion to $\mathrm{NaCl}$, their results are difficult to interpret.

The present experiment reports on amygdaloid lesion-induced failure to form a learned aversion to saccharin solution which avoids these difficulties.

\section{METHOD \\ Subjects}

The Ss were 15 male albino rats (Holtzman Co.), 225-250 days old at the beginning of the experiment. These Ss had previously served in studies of exploratory behavior, wood gnawing, and passive avoidance but had had no previous experience with the solutions to be tested in this experiment.

\section{Surgery and Histology}

Surgical techniques are described in detail elsewhere (Kemble

*The authors would like to thank Merle Hirsch for supplying the $\mathrm{LiCl}$ used in this experiment.
\& Beckman, 1970). Briefly. bilateral anodal electrolytic lesions $(2.0 \mathrm{~mA} / 20 \mathrm{sec})$ were sterotactically placed in the amygdaloid complex of seven Ss through stainless steel insect pins. Two Ss received control operations and the remaining $\mathrm{Ss}$ received scalp incisions only.

At the conclusion of testing, experimental brains were examined histologically. The amygdaloid lesions were similar in size and placement to those reported previously (Kemble \& Beckman, 1970).

\section{Apparatus and Procedures}

All testing conducted in cages (Wahmann, LC-28) adapted to accept two $100-\mathrm{ml}$ drinking tubes housed in a continuously illuminated animal room. All solutions were freshly mixed in deionized water on the day of use.

Initially, all Ss were deprived of food and water for $23 \mathrm{~h}$ and given $5 \mathrm{~h}$ access to a $0.1 \%$ saccharin solution $(1.0 \mathrm{~g} / 1,000 \mathrm{ml})$ and tap water (pretreatment). Amygdaloid and control Ss were then designated to receive $\mathrm{LiCl}$ (control, $\mathrm{N}=4$; amygdaloid, $\mathrm{N}=4$ ) or isotonic saline (control, $\mathrm{N}=4$; amygdaloid, $\mathrm{N}=3$ ) injections during the aversion trial. After $24 \mathrm{~h}$ ad lib access to food and water, all Ss were deprived of food and water for $23 \mathrm{~h}$ and then permitted to drink $0.1 \%$ saccharin solution (only) for $10 \mathrm{~min}$. After $10 \mathrm{~min}$ access to saccharin solution, Ss received a $6-\mathrm{ml}$ intraperitoneal injection of $0.12 \mathrm{M} \mathrm{LiCl}$ or isotonic saline; they were then returned to their cages and given ad lib access to food and water for $48 \mathrm{~h}$. Finally, Ss were food and water deprived for $23 \mathrm{~h}$ and given $5 \mathrm{~h}$ access to $0.1 \%$ saccharin solution and tap water as described above (posttreatment).

\section{RESULTS AND DISCUSSION}

The results of this experiment are summarized in Table 1. It can be seen that, with one exception, all Ss showed a strong preference for saccharin solution before treatment. After treatment with $\mathrm{LiCl}$, control Ss typically rejected saccharin while all amygdaloid Ss

Table 1

Percent Saccharin Solution in Total Fluid Intake During Preference Testing Before (Pretreatment) and After (Posttreatment) Injection of $0.12 \mathrm{~m} \mathrm{LiCl}$ or Isotonic Saline

\begin{tabular}{lccc}
\hline & & \multicolumn{2}{c}{$\begin{array}{c}\text { Percent Saccharin } \\
\text { Solution in Total Intake }\end{array}$} \\
\cline { 2 - 4 } Group & $\begin{array}{c}\text { S } \\
\text { Number }\end{array}$ & $\begin{array}{c}\text { Pre- } \\
\text { treatment }\end{array}$ & $\begin{array}{c}\text { Post- } \\
\text { treatment }\end{array}$ \\
\hline Control & 3 & 91.8 & 11.8 \\
(LiCl Treated) & 8 & 92.9 & 90.6 \\
& 16 & 92.1 & 22.2 \\
Amygdaloid & 17 & 97.5 & 23.1 \\
(LiCl Treated) & 15 & 91.8 & 64.0 \\
& 18 & 100.0 & 96.0 \\
Control & 21 & 98.5 & 95.5 \\
(Saline Treated) & 23 & 95.7 & 96.2 \\
& 13 & 46.7 & 81.8 \\
Amygdaloid & 14 & 96.8 & 95.7 \\
(Saline Treated) & 20 & 90.5 & 84.3 \\
& 19 & 87.8 & 89.3 \\
& 22 & 88.6 & 94.4 \\
& 24 & 97.2 & 98.8 \\
& & 96.6 & 94.7 \\
\hline
\end{tabular}


drank substantial amounts of this solution $(U=1$, $\mathrm{df}=4 / 4, \mathrm{p}<.03)$. Both control and amygdaloid Ss continued to show a strong preference for saccharin solution after treatment with saline solution. Alternatively, if reactivity is indexed by amount of saccharin solution consumed (instead of a percent measure), closely parallel results are obtained. Although amygdaloid Ss drank slightly more saccharin solution $(\bar{X}=56.0 \mathrm{ml})$ than control Ss $(\bar{X}=40.6 \mathrm{ml})$ during the pretreatment test, these differences did not approach statistical significance $(\mathrm{p}>.10)$. After treatment with $\mathrm{LiCl}$, amygdaloid Ss drank significantly $(\mathrm{U}=1, \mathrm{df}=4 / 4$, $\mathrm{p}<.03)$ more saccharin solution $(\bar{X}=39.2 \mathrm{ml})$ than did control Ss $(\bar{X}=9.0 \mathrm{ml})$. Finally, the posttreatment saccharin consumption of saline-treated amygdaloid $(\overline{\mathrm{X}}=$ $43.7 \mathrm{ml})$ and control Ss $(\overline{\mathrm{X}}=35.8 \mathrm{ml})$ did not differ reliably.

The present data are consistent with that of McGowan et al (1972) and Rolls \& Rolls (1973) in suggesting an important role for the amygdaloid complex in the formation of learned taste aversions. Moreover, the pretreatment data indicate that this deficit does not reflect hyperreactivity to the test solutions. Neither would a general disorder of fluid intake or ingestive mechanisms seem to account for the amygdaloid deficit. Rolls \& Rolls (1973) report normal responsivity in hypertonic saline- or ispoproterenol-induced drinking in amygdaloid Ss, and we have observed quite normal adaptation to food and water deprivation as well as cellulose-adulterated food in our laboratory (Kemble, unpublished observations). Thus, taste aversion may be added to the impressive list of aversively motivated behaviors disrupted by amygdaloid insult.

\section{REFERENCES}

Goddard, G. V. Functions of the amygdala. Phychological Bulletin, 1964, 62, 89-109.

Horvath, F. E. Effects of basolateral amygdalectomy on three types of avoidance behavior in cats. Journal of Comparative \& Physiological Psychology, 1963, 56, 380-389.

Kemble, E. D., \& Beckman, G. J. Runway performance of rats following amygdaloid lesions. Physiology \& Behavior, 1970, 5, 45-47.

McGowan, B. K., Hankins, W. G., \& Garcia, J. Limbic lesions and control of the internal and externam environment. Behavioral Biology, 1972, 7, 841-852.

Pellegrino, L. J. Amygdaloid lesions and behavioral inhibition in the rat. Journal of Comparative \& Physiological Psychology, $1968,65,483-491$.

Rolls, B. J., \& Rolls, E. T. Effects of lesions in the basolateral amygdala on fluid intake in the rat. Journal of Comparative \& Physiological Psychology, 1973, 83, 240-247.

Rozin, P., \& Kalat, J. W. Specific hungers and poison avoidance as adaptive specializations of learning. Psychological Review, $1971,78,459-486$.

Ursin, H. Ef fect of amygdaloid lesions on avoidance behavior and visual discrimination in cats. Experimental Neurology, $1965,11,298-317$.

(Received for publication June 18, 1973.) 